\title{
Left ventricular diastolic dysfunction in chronic renal failure patients on chronic hemodialysis in Dr. Cipto-Mangunkusumo Hospital : the association with left ventricular mass
}

\author{
Idrus Alwi ${ }^{*}$, S Harun ${ }^{*}$, H Prabowo ${ }^{f}$, Soehardjono ${ }^{\S}$, HB Trisnohadi ${ }^{*}$, A Muin Rahman ${ }^{*}$, Dasnan Ismail ${ }^{*}$
}

\begin{abstract}
Abstrak
Empat puluh tiga kasus pasien gagal ginjal kronik ( GGK) yang menjalani dialisis kronik di Divisi Ginjal Hipertensi, Fakultas Kedokteran Universitas Indonesia/Rumah Sakit Umum Pusat Nasional Dr Cipto Mangunkusumo, Jakarta, selama bulan Oktober 2003 sampai dengan bulan Februari 2004, dilakukan pemeriksaan ekokardiografi untuk melihat fungsi diastolik ventrikel kiri dan penilaian indeks massa ventrikel kiri. Disfungsi diastolik ditemukan pada 58.1 \% pasien GGK yang menjalani dialisis kronik. Tidak terdapat perbedaan bermakna rerata massa ventrikel kiri pada kelompok dengan disfungsi diastolik dibandingkan kelompok tanpa disfungsi diastolik. (Med J Indones 2006; 15:105-8)
\end{abstract}

\begin{abstract}
Fourty three patients with chronic renal failure undergoing chronic hemodialysis in Division of Nephrology and Hypertension, Faculty of Medicine, University of Indonesia/Cipto-Mangunkusumo Hospital, Jakarta, since October 2003 until February 2004 , were examined for echocardiography (2-D, M-mode, Doppler imaging ).Diastolic dysfunction was found in $58.1 \%$ of chronic renal failure patients on hemodialysis. There was no significant difference between left ventricular mass in the group with or without left ventricular diastolic dysfunction. (Med J Indones 2006; 15:105-8)
\end{abstract}

Keywords: Left ventricular mass, diastolic function, chronic renal failure, hemodyalisis

An epidemiological ${ }^{1}$, clinical and echocardiographics studies $^{2,3}$ showed that patients with chronic renal failure include patients with chronic hemodialysis ${ }^{4,5}$ have abnormalities of both left ventricular structure and function. Cardiovascular disease is the most common cause of death in dialysis subject. ${ }^{6}$

Gagliardi GM et $\mathrm{al}^{5}$, reported prevalence of diastolic dysfunction in chronic renal failure patients on hemodialysis about $77.4 \%$. Left ventricular diastolic function studies in chronic renal failure patients, especially on hemodialysis in Indonesia has not been reported.

\footnotetext{
* Division of Cardiology Department of Internal Medicine, Faculty of Medicine University of Indonesia / Dr. Cipto Mangunkusumo General Hospital, Jakarta, Indonesia

${ }^{f}$ Department of Internal Medicine, Faculty of Medicine University of Indonesia / Dr. Cipto Mangunkusumo General Hospital, Jakarta, Indonesia

$\S$ Division of Nephrology and Hypertension, Department of Internal Medicine, Faculty of Medicine University of Indonesia / Dr. Cipto Mangunkusumo General Hospital, Jakarta, Indonesia
}

In adults with hypertension and chronic renal failure, left ventricular hypertrophy (LVH) is thought to be initially adaptive to improve contractility and lower stress in the face of increased afterload (blood pressure) and preload (volume). The progression of renal failure frequently leads to systolic dysfunction, which is associated with clinical signs of cardiac failure and decreased survival. ${ }^{7,8}$

The association between left ventricular mass and left ventricular diastolic function in chronic renal failure patients on chronic hemodialysis in Indonesia has not been reported. The aims of this study were to evaluate diastolic function in chronic renal failure patients on hemodialysis and determine the association between left ventricular mass and left ventricular diastolic function.

\section{METHODS}

This was a cross sectional study at Dialysis Unit Division of Nephrology and Hypertension and Division of Cardiology Department of Internal Medicine Faculty 
of Medicine University of Indonesia / Ciptomangunkusumo Hospital. The study began in October 2003 and was completed by February 2004. The diagnosis of chronic renal failure was established base on creatinin clearance and ultrasonography.

All patients had a history and physical examination. Clinical data were collected on the day of the echocardiography evaluation including height, weight, body mass index, heart rate, systolic blood pressure (SBP), diastolic blood pressure (DBP) and hemoglobin.

\section{Echocardiography}

Echocardiograms were recorded with acommercially available ultrasound system (Apogee CX 200). Subjects were examined in the left lateral decubitus position using standard parasternal, short-axis, and apical views. All recordings and measurements were obtained by the same observer according to the recommendations of the American Society of Echocardiography. ${ }^{9}$

The measurement of transmitral blood flow velocity and Doppler pulse sample volume were put on the middle of mitral annulus. In addition, transmitral Doppler flow pattern : peak E velocity in centimeters per second (peak early transmitral filling velocity during early diastole), peak A velocity in centimeters per second (peak transmitral atrial filling velocity during late diastole). Then, the E/A ratio and deceleration time in milliseconds (time elapsed between peak $\mathrm{E}$ velocity and the point where the extrapolation of the deceleration slope of the E velocity crosses the zero baseline) were calculated.

Pulmonary venous flow recordings were obtained from the four-chamber view directed at the right upper pulmonary vein. Sample volume was obtained $1-2 \mathrm{~cm}$ into the pulmonary vein, and the following measurements were carried out: peak $S$ wave velocity in centimeters per second (peak systolic pulmonary venous inflow velocity during ventricular systole), peak $D$ wave velocity in centimeters per second (peak diastolic pulmonary venous inflow velocity during early phase of atrial diastole), and peak $A$ wave velocity in centimeters per second (peak reversed systolic wave during atrial contraction). ${ }^{10}$

The definitions published by the Canadian consensus on diastolic dysfunction by echocardiography were used to classify diastolic function as follows: normal, impaired relaxation, pseudonormal, and restrictive pattern. All cardiac valves were examined to rule out significant valvular disease. ${ }^{11}$
Left ventricular mass was calculated with formula : $\operatorname{LVM}(\mathrm{g})=0.8 \times 1.04(\text { LVEDD + IVST + PWT })^{3}-$ $(\text { LVEDD })^{3}+0.6$, LVEDD was left ventricle end diastolic internal diameter, IVST was interventricular septal thickness and PWT was posterior wall thickness. ${ }^{12}$

\section{Statistic Analysis}

Values are presented as mean \pm SD. A 2 sample $t$ test was used to compare mean \pm SD of continuous variables. $\mathrm{P}<0,05$ was considered statistically significant.

\section{RESULTS}

\section{Patient Characteristics}

The main demographic and clinical characteristics are presented in table 1 .

Table 1. Patients Characteristics

\begin{tabular}{lc} 
Age,y & $52.09 \pm 10.75$ \\
Body Surface Area (BSA) & $1.6 \pm 0.18$ \\
Systolic blood pressure (SBP) ( mm Hg) & $154.42 \pm 24.52$ \\
Diastolic blood pressure (SBP) ( mm Hg) & $91.40 \pm 9.15$ \\
Hemoglobin, g/dl & $9.03 \pm 0.95$ \\
Left ventricular mass & $257.04 \pm 101.63$ \\
Left ventricular mass index (LVMI) & $159.97 \pm 3.49$ \\
Duration of hemodialysis, y & $4.12 \pm 3.49$ \\
\hline
\end{tabular}

Table 2 showed clinical characteristic patients with normal diastolic function and abnormal diastolic function. There were $18(41.86 \%)$ patients with abnormal relaxation, $6(13.95 \%)$ patients with pseudonormal and $1(2.3 \%)$ patients with restrictive pattern (figure 1).

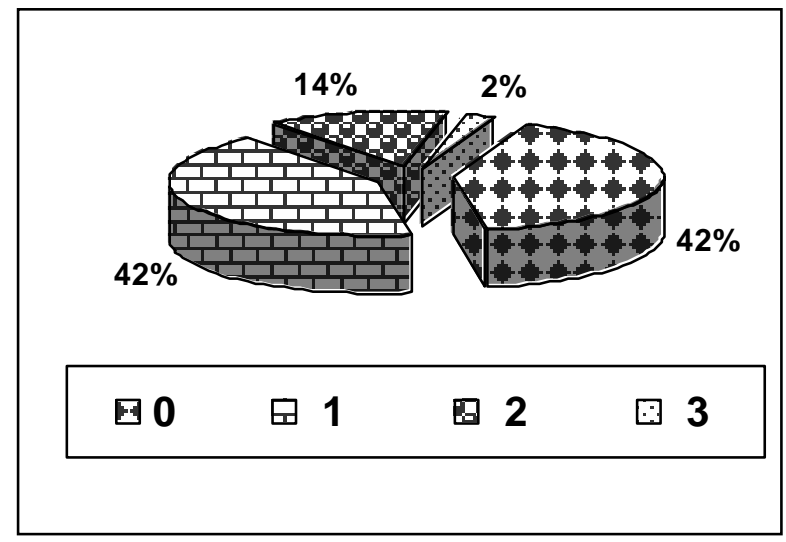

Figure 1. Distribution of diastolic dysfunction

$0=$ normal diastolic function, $1=$ relaxation abnormality, $2=$ pseudonormal, $3=$ restrictive pattern 
There were no significant difference in body surface area, systolic blood pressure, diastolic blood pressure, pulsed pressure, hemoglobin levels and duration of hemodialysis between the 2 groups. The age in group
B was higher than group A, but the ages of the all patients was $<60 \mathrm{y}$. Also there were no significant difference in LVM and LVMI between the two groups.

Tabel 2. Clinical Characteristics

\begin{tabular}{|c|c|c|c|}
\hline & $\begin{array}{c}\text { No diastolic function } \\
\text { Group A } \\
(\mathrm{n}=18)\end{array}$ & $\begin{array}{c}\text { Diastolic function } \\
\text { Group B } \\
(n=25)\end{array}$ & $\mathrm{P}$ \\
\hline Age,y & $48.06 \pm 11.55$ & $55.09 \pm 1.86$ & 0.035 \\
\hline Body surface area (BSA) & $1.57 \pm 0.19$ & $1.62 \pm 0.18$ & 0.384 \\
\hline Systolic blood pressure $(\mathrm{mmHg})$ & $161.11 \pm 26.76$ & $149.60 \pm 22.08$ & 0.089 \\
\hline Diastolic blood pressure $(\mathrm{mmHg})$ & $92.78 \pm 10.18$ & $90.40 \pm 8.41$ & 0.357 \\
\hline Pulse pressure & $68.33 \pm 20.36$ & $59.20 \pm 20.60$ & 0.157 \\
\hline Hemoglobin, g/dl & $8.93 \pm 0.1$ & $9.11 \pm 0.92$ & 0.536 \\
\hline Left ventricular mass (LVM) & $271.35 \pm 123.04$ & $246.73 \pm 84.18$ & 0.440 \\
\hline Left ventricular mass index (LVMI) & $171.84 \pm 70.79$ & $151.43 \pm 45.20$ & 0.255 \\
\hline Duration of hemodialysis & $3.56 \pm 2.26$ & $4.52 \pm 4.16$ & 0.301 \\
\hline
\end{tabular}

There was no difference in left ventricular ejection fraction (LVEF) between the 2 groups ( group A LVEF $65.39 \pm 12.31$ vs group B LVEF $62.68 \pm 14.83$ )

Tabel 2. Left Ventricular Diastolic Filling

\begin{tabular}{|c|c|c|c|}
\hline & $\begin{array}{l}\text { No diastolic function } \\
\text { (Group A ) } \\
(\mathrm{n}=18)\end{array}$ & $\begin{array}{l}\text { Diastolic function } \\
\text { (Group B) } \\
(\mathrm{n}=25)\end{array}$ & $\mathrm{p}$ \\
\hline E velocity $(\mathrm{cm} / \mathrm{s})$ & $113.33 \pm 21.13$ & $81.12 \pm 28.41$ & 0.000 \\
\hline A velocity $(\mathrm{cm} / \mathrm{s})$ & $80.28 \pm 16.14$ & $82.32 \pm 35.02$ & 0.799 \\
\hline Deceleration time (DT) & $211.67 \pm 61.38$ & $247.60 \pm 75.29$ & 0.104 \\
\hline Isovolumic relaxation time (IVRT) & $108.89 \pm 30.85$ & $129.60 \pm 30.34$ & 0.003 \\
\hline MVa ( A wave duration ) & $122.22 \pm 33.70$ & $123.20 \pm 26.88$ & 0.620 \\
\hline PV systolic (S) & $52.67 \pm 9.60$ & $44.44 \pm 17.20$ & 0.074 \\
\hline PV diastolic (D) & $61.61 \pm 18.28$ & $38.28 \pm 12.60$ & 0.000 \\
\hline PVa (atrial systolic reversal) & $104.44 \pm 30.91$ & $110.80 \pm 24.31$ & 0.377 \\
\hline PV velocity & $19.94 \pm 3.04$ & $23.96 \pm 5.98$ & 0.01 \\
\hline
\end{tabular}

As compared to group A, Group B showed a significantly lower mitral E velocity, a longer IVRT, and a higher PV velocity. 


\section{DISCUSSION}

Diastolic function study in chronic renal failure patients on hemodialysis in Indonesia has not been reported. In this study prevalence of diastolic dysfunction was $58.1 \%$. Gagliardi GM et $\mathrm{al}^{5}$ reported prevalence of diastolic dysfunction in 31 dialysis patients (26 on hemodialysis, 5 on peritoneal dialysis ) was $77.4 \%$.

Left ventricular hypertrophy $(\mathrm{LVH})$ is the main manifestation of uremic cardiomyopathy and predicts both cardiovascular events and death, independently of conventional risk factors. Diastolic dysfunction is often associated with left ventricular hypertrophy, and accounts for up to $30 \%$ of heart failure. The association between LVH and left ventricular diastolic function on hemodialysis patients was reported by Gagliardi GM et $\mathrm{al}^{5}$. They showed left ventricular hypertrophy in $71 \%$ patients (eccentric LVH $55 \%$, and concentric LVH in $16 \%$ patients). Left ventricular hypertrophy is associated with diastolic dysfunction, and both cause of hypotensive episodes during dialytic treatments and heart failure in patients with normal systolic function.

In this study there was no significant differences in left ventricular mass between the groups with diastolic dysfunction and group without diastolic dysfunction. We suggested that there were many factors involved in diastolic dysfunction eg; diabetes mellitus and hypertension. Miyazato et $\mathrm{al}^{2}$ studied impact of diabetes mellitus on left ventricular diastolic dysfunction in patients with non dialysis chronic renal failure, independent of LVH. They suggested that left ventricular diastolic dysfunction, independent of $\mathrm{LVH}$, is specifically and makedly progressed in patients with chronic renal failure as a result of diabetic nephropathy. Another reason was the sample in this study may be to small.

This is the first study in Indonesia that reported the association between left ventricular mass and left ventricular diastolic dysfunction in chronic renal failure patients on hemodialysis. There was no siginificant difference left ventricular mass and diastolic dysfunction.

\section{CONCLUSSION}

Prevalence of diastolic dysfunction in chronic renal failure patients on hemodialysis was $58.1 \%$. There was no significant difference between left ventricular mass in the group with or without left ventricular diastolic dysfunction. The non invasive assessment of left ventricular diastolic function would represent an important advancement in the diagnosis and prevention of heart failure in hemodialysis patients.

\section{REFERENCES}

1. Foley RN, Parfrey PS, Sarnak MJ. The clinical epidemiology of cardiovascular disease in chronic renal disease. Am J Kidney Dis 1998; 32:S112-S119.

2. Miyazato J, Horio T, Takiuchi $\mathrm{S}$ et al. Left ventricular diastolic dysfunction in patients with chronic renal failure: impact of diabetes mellitus. Diabet Med 2005; 22(6):730-6.

3. Mitsnefes MM, Kimball TR, Border WL et al, Impaired left ventricular diastolic function in children with chronic renal failure. Kidney Int. 2004; 65(4):1461-6.

4. Furth S, Hermann JA, Powe NR. Cardiovascular risk factors, comorbidity, and survival outcomes in black and white dialysis patients. Semin Dial 1998; 11:1-4.

5. Gagliardi GM, Rossi S, Manes MT. et al. Impact of left ventricular patterns and diastolic dysfunction on hemodialysis patients. G Ital Nefrol 2004; 21(1):45-50.

6. Harnett JD, Foley RN, Kent GM, et al. Congestive heart failure in dialysis patients: prevalence, incidence, prognosis and risk factors. Kidney Int 1995; 47(3):884-90.

7. Ganau A, Devereux RB, Pickering TB, et al. Relationship of left ventricular hemodynamic load and contractile performance to left ventricular mass in hypertension. Circulation 1990; 81:25-36.

8. Dahan M, Siohan P, Viron B, et al. Relationship between left ventricular hypertrophy, myocardial contractility, and load conditions in hemodialysis patients: an echocardiographic study. Am J Kidney Dis. 1997; 30:780-5.

9. Sahn DJ, DeMaria A, Kisslo J, et al. The Committee on M-mode Standardization of the American Society of Echocardiography: recommendations regarding quantitation in M-mode echocardiography. Results of a survey of echocardiographic measurements. Circulation 1978; 58:1072-83.

10. Oh JK, Appleton CP, Hatle LK, Nishimura RA, Seward JB, Tajik JA. The noninvasive assessment of left ventricular diastolic function with two dimensional and Doppler echocardiography. J Am Soc Echocardiogr 1997; 10:246-70.

11. Rakowski H, Appleton C, Chan KL, Dumesnil JG, Honos G, Jue J, Koilpillai C, Lepage S, Martin RP, Mercier LA, O’Kelly B, Prieur T, Sanfilippo A, Sasson Z, Alvarez N, Pruitt R, Thompson C, Tomlinson C: Canadian consensus recommendations for the measurement and reporting of diastolic dysfunction by echocardiography: from the Investigators of Consensus on Diastolic Dysfunction by Echocardiography. J Am Soc Echocardiogr 1996; 9:736-60

12. Guidelines from the Canadian Cardiovascular Society and the Canadian Hypertension Society on the echocardiographic determination of left ventricular mass (Consensus Statement). Task Force of the Echocardiography Section. Can J Cardiol 1995;11:391-5. 